Cezary NAUMOWICZ

WSnR UKSW Warszawa

\title{
Ecology and Anthropology in Ecofeminist Theology
}

Ecofeminism is a movement that sees a connection between the degradation of the natural world and the subordination and oppression of women. It emerged in the early 1970s in North America and Europe alongside second-wave feminism and the green movement. Ecofeminism can be presented as a convergence of the ecological and feminist analyses which represents varieties of theoretical, practical and critical efforts to understand and resist the interrelated dominations of women and nature. That is why we find in that movement a diversity of approaches, concerns, perspectives and political goals.

An ecofeminist theologian Rosemary Radford Ruether said in the early 1970s: „Since women in Western culture have been traditionally identified with nature, and nature in turn has been seen as an object of domination by man (males), it would seem almost a truism that the mentality that regarded the natural environment as an object of domination drew upon imagery and attitudes based on male domination of women"1. It was an early link between ecofeminism and theology as it was evident to ecofeminist theologians that the Jewish and Christian traditions were implicated in fostering the dual oppression of women and nature.

\footnotetext{
R.R. Ruether, New Woman/New Earth: Sexist Ideologies and Human Liberation, New York 1975, 186; cf. Id., Integrating Ecofeminism, Globalisation, and World Religions, Lanham 2005, 91ff; Id., Religious Ecofeminism: Healing the Ecological Crisis, in: The Oxford Handbook of Religion and Ecology, R.S. Gottlieb (ed.), Oxford 2006, 362ff. E. Green, Al crocicchio delle strade. Teologia femminista all'inizio del XXI secolo, in: Prospettive teologiche per il XXI secolo, R. Gibellini (ed.), Brescia 2003, 169-182, 178: „Il parallelismo tra oppressione delle donne e sfruttamento della natura è stato una costante del pensiero teologico ecofemminista praticato da studiose come Rosemary Radford Ruether". Cf. also M. Mellor, Feminism and Ecology, New York 1997, 50ff; J. MAJEWSKI, Seksizm a teologia (Rosemary Radford Ruether), in: Leksykon wielkich teologów XX i XXI wieku, J. Majewski, J. Makowski (eds.), Warszawa 2003, 294-303; Id., Teologia na rozdrożach, Kraków 2005, 45-94.
} 


\section{Ecology, feminism, theology}

The ecological crisis is creating a new context for theology. An ecological crisis of this magnitude has never existed previously. Prior to ecofeminism, the ecological crisis and feminist analyses were independently influencing theological reflections. Ecofeminism can be seen as a combination of both these challenges. Ecofeminism is often more radical than other voices in ecotheology ${ }^{2}$ because it has already rejected hierarchical dualisms. Ecofeminist theology is to be understood as a loose term denoting the contributions that join together ecology, theology and feminism ${ }^{3}$. The joining together of ecology, feminism and theology is an interdisciplinary venture. Some authors put emphasis on the ecological dimension and their main dialogue partner are the earth sciences. For others the dialogue partner are the social sciences. For others the primary reference point is theology, Bible and traditions.

Women and the natural world are interlaced in a complex synthesis of hierarchical dualisms embedded in a patriarchal worldview and social structures. Ecofeminist theologians claim that Christianity has been one of the chief proponents of this worldview. However ecofeminists maintain that the role of Christianity in the dual subjugation of women and the natural world is evident but not straightforward because Christianity represents many things. Some feminists reject Christianity completely and more moderate authors believe that a radical reformulation of Christianity through a demythologization of its patriarchal categories comes closer to the real truth of the Christian faith. Heather Eaton claims that the challenge of feminism to Christianity has been massive but the challenge of ecofeminism is even greater ${ }^{4}$. We portray here examples of more moderate positions and views.

Elizabeth Johnson summarizes: „I am persuaded by the truth of the ecofeminist insight that analysis of the ecological crisis does not get to the heart of the matter until it sees the connection between the exploitation of the earth and the sexist definitions and treatment of women (...) and these distortions

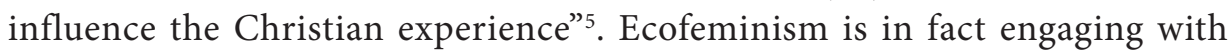
reformulation of several aspects of Christian theology. Questions are asked about what central Christian notions might mean in the light of the ecological crisis and within an ecological paradigm. It leads to some doctrinal reinterpretations.

2 Ecotheology stands for all the work that brings together ecological and theological views. Cf. C. Naumowicz, Eko-teologia jako forma chrześcijańskiej diakonii wobec stworzenia, Studia Ecologiae et Bioethicae 7,1 (2009) 221-233.

3 Cf. H. Eaton, Ecological-Feminist Theology: Contributions and Challenges, in: D. Hessel (ed.), Theology for Earth Community: A Field Guide, Maryknoll 1996, 77-92.

4 Cf. H. Eaton, Introducing Ecofeminist Theologies, London - New York 2005, 62ff.

5 E. Johnson, Women, Earth, and Creator Spirit, New York 1993, 10. 
The monarchical patriarchal male image of God has blinded us to the sacredness of the earth and has excluded women, all non-human animals and the earth from the sphere of the Sacred. E. Johnson suggests that God can be seen as spirit within and among us: sustaining and creating all life in an everpresent dynamic of new possibilities. One can take this image and reinterpret creation, anthropology, spirituality and ethics. An understanding of the spirit as permeating all life challenges anthropocentrism (human-centredness reflecting human domination over nature) and androcentrism (male-centredness reflecting male domination over women and nature $)^{6}$.

According to Sally McFague the monarchical model of God has "three major flaws": „God is distant from the world, relates only to the human world, and controls that world through domination and benevolence"' . For R. Ruether a monarchical concept of God is a projection of masculine desire for absolute autonomy, transcendence and infinity. Ecofeminist theology conceives God as more immanent to the world's processes. Mutuality replaces dominance and submission in the God-world relationship and female symbols and metaphors become vehicles of the divine. Mary Grey argues that women are open „to admit and welcome the sacredness of the earth as humanity's true home"s.

\section{Earth-centered, cosmological approaches}

$\mathrm{H}$. Eaton underlines in ecofeminist theologies two particular themes, the dialogue with the earth sciences and the global work in ecofeminist liberation theologies. Ecofeminist theologians try to reinterpret theological categories from an ecofeminist viewpoint. They examine systematic theology and try to stretch basic tenets to incorporate ecofeminist viewpoints. Many theologians consider that the usual starting points for theology (scriptural texts, doctrines, symbols) are insufficient in dealing with the ecological crisis. They turn to other conversation partners like earth sciences. The second partner involves socialpolitical analysis and transformation, with attention to multicultural and multireligious aspects?.

Ecotheologians try to repair the rupture between Christian theology and the natural world. They reclaim lost elements such as a reverence for the natural world, rework existing symbols and doctrines and construct new viewpoints.

6 M. Kheel, Ecofeminism and Deep Ecology: Reflections on Identity and Difference, in: I. Diamond, G.F. Orenstein (eds.), Reweaving the World: The Emergence of Ecofeminism, San Francisco 1990, 129: „Whereas the anthropocentric worldview perceives humans as the center or apex of the natural world, the androcentric analysis suggests that this worldview is unique to men".

S. McFague, Models of God. Theology for an Ecological Nuclear Age, London 1987, 65.

M. Grey, Redeeming the Dream: Feminism, Redemption and Christian Tradition, London 1989, 48.

9 Cf. H. Eaton, Introducing Ecofeminist Theologies, op. cit., 92 f. 
Many ecofeminist theologians work in the area of evolution and cosmology. Cosmology has several meanings, but in this context R. Ruether describes cosmology as „(...) a view of the relation of humans to the rest of nature, their relation to each other in society, and their relation to the ultimate foundational source of life (the divine). They have been blueprints for what today we would call a combined scientific, social-ethical, and theological-spiritual worldview"10. Ecofeminists argue that theology needs to recover the universality of its tasks, with a further enlargement of theological horizons to attend to cosmology by reinstating the cosmos into the realm of the sacred ${ }^{11}$.

With the rise of modernity, Euro-western cultures dropped cosmology as a horizon out of which we comprehend our lives. The cosmos and the earth are presented to us in a machinelike manner and they are not alive and have no intrinsic value. The prevailing anthropocentric worldview includes the earth only as a resource. We need a deep shift in cosmology that challenges the disenchanted view that the universe lacks any ultimate purpose, has no transcendent origins and has no divinely shaped destiny. Cosmology is involved in recasting the worldview of modernity to change our thinking about the earth. Ecofeminists join these efforts and bring important insights in the move beyond a mechanistic worldview to a holistic postmodern ecological cosmology.

For centuries the predominant theological focus has been on anthropocentric and individual concerns. Theology neglected a meaningful doctrine of creation and an awareness of the natural world. According to ecofeminist theologians to conceive Christianity in light of an evolutionary cosmology calls for substantial re-evaluations of some theological assertions. Ecotheologians deal with, what they believe, the Christian emphasis on humanity's transcendence which desacralize the natural world. A cosmological or evolutionary starting point has moved most ecotheologians to conclude that the primary religious story is that of the emergence of life.

S. McFague suggests that such a common creation story could become the beginning of an „evolutionary, ecological, theological anthropology that could have immense significance transforming how we think about ourselves and our relations and responsibilities toward other human beings, other species, and our home, planet Earth"12.

10 R.R. Ruether, Gaia and God: An Ecofeminist Theology of Earth Healing, San Francisco 1992, 32.

11 According to Anne Clifford, such a cosmic theology would be involved in the following: „(...) deepening in the 'coherence of worldview' in which the continuity within creation - humans and all earth's life forms within the totality of cosmic process - will be appreciated and reverenced in the light of God [and] a shared commitment to the ecological well-being of that part of the cosmos that we share and reverence as gift". A. Clifford, Feminist Perspectives on Science: Implications for an Ecological Theology of Creation, Journal of Feminist Studies in Religion 8 (1992) 65-92, here 33. Cf. L. Rasmussen, Cosmology and Ethics, in: M.E. Tucker and J. Grim (eds.), Worldviews and Ecology, Lewisburg 1993, 173-180, spec. 174.

12 S. McFague, The Body of God: An Ecological Theology, Minneapolis 1993, 33. 
S. McFague claims that the world is our meeting place with God. It is wondrous, awesomely and divinely mysterious. Yet this world is being destroyed. S. McFague's work is directed to theology, but with the goal of stemming the ecological devastation. She uses science as a start point with an emphasis on the process out of which the earth emerged, namely cosmology and on evolutionary earth process from which emerged all life. S. McFague underlines the significance of cosmology to both theology and to attitudes toward the natural world. She moves among various assumptions of creation, anthropology, Christology and eschatology extending to each a theology of the world as God's body (embodied transcendence of God). God the mother gives birth to her body, the world. We are invited to see the Creator in the creation. It is a sort of radicalization of incarnation: God is present not only in Christ, although this presence is paradigmatic, but is present in the whole of the world as her body. It is not a pantheistic vision but panentheistic. She claims: God is not identical with the universe, because the universe depends on God in the way that God does not depend on the universe ${ }^{13}$.

If theology were to consider the earth to be the basic context of its reflection this would suggest a common agenda for all theological endeavour. Such a process would involve an ongoing deconstruction of the anthropocentrism, androcentrism and hierarchical dualisms that have permeated many of the theological depictions of reality, and cause the socio-ecological wreckage. According to S. McFague this cosmological framework in reinterpretation of theological convictions would "turn the eyes of theologians away from heaven and towards the earth; or more accurately, it causes us to connect the starry heavens with the earth, as the common creation story claims (...). In whatever ways we might reconstruct the symbols of God, human being, and earth, this can no longer be done in a dualistic fashion, for the heavens and the earth are one phenomenon, albeit an incredibly ancient, rich and varied one"14. We should not view the earth through an arrogant eye as if it were a machine that we seek to control. We need to pay attention to the earth and the embodied model of God helps us to come in tune with the earth and become conscious of its vibrant subjectivity. Our mistreatment of nature becomes a sin against God's body ${ }^{15}$.

S. McFague's later books gives much greater attention on the social and cultural issues. However, she still holds to her earlier position combining the organic models through the panentheistic metaphor of the world as God's body. Her views allow for some distinction between God and the world, in comparison for example with a more explicitly pantheistic vision of Grace Jatzen ${ }^{16}$.

\footnotetext{
Cf. Ibidem, $133 \mathrm{ff}$

Ibidem, 87.

Cf. S. McFague, Models of God, op. cit., 113.

Cf. G. Jatzen, God's World, God's Body, Philadelphia 1984.
} 
As Celia Deane-Drummond rightly notes: „Yet we need to question how helpful the image of the body might be for an understanding of God in feminist terms. Bodies today become subjects that can be manipulated and altered through medical practices and technology; consumerism pressures women to conceive of idealistic images of the body; cyberspace replaces the image of the body with a virtual world that is no longer subject to earthly constraints. All such cultural trends give bodiliness as such an ambiguity that then can overshadow any more positive advantages of such identification"17.

R. Ruether surveyed three classical creation narratives: Babylonian, Hebrew, Greek and their relationship to Christian creation stories. From an ecofeminist analysis she found here core distortions and limitations. She revealed their antiwomen and anti-nature stances, and showed how these have influenced theological formulations of the doctrine of creation, eschatology and soteriology. She proposes an ecofeminist theocosmology claiming that Christianity could be reconnected to its earthly and cosmic dimensions through our contemporary scientific understanding of the earth and the cosmos. It could provide a worldview from which we can discover and develop ethics oriented towards responding to the ecological crisis. If Christianity were reoriented towards a cosmological horizon it may foster a renewed spirituality of earth. Such an ecological spirituality would awaken a sense of kinship and communion with the earth community filling our spirits with compassion. We should embrace both the earth and God, or as she wrote both Gaia and God ${ }^{18}$.

Another ecofeminist theologian who has entered deeply into the conversations between theology and science is Anne Primavesi. Her reflection is based on the Gaia hypothesis as developed by James Lovelock ${ }^{19}$. The Gaia hypothesis supports an evolutionary and scientific understanding of the earth and suggests that the earth functions like a whole organism, maintaining sophisticated equilibrium barely perceptible to humans. The distinctions between plant and animal, living and nonliving, and spirit and matter do not make sense from an earth sciences viewpoint. This knowledge is then brought to bear upon the Christian theological system with its hierarchical and Christocentric claims. A. Primavesi is one of those ecofeminists who uses earth science radically in depth. In her reflections theology becomes another earth science. Similar to others A. Primavesi criticizes Christianity for only considering human history as relevant for the stories and cultures of particular

17 C. Deane Drummond, Eco-theology, London 2008, 151.

18 Cf. R.R. Ruether, Gaia and God, op. cit., 249ff. R. Gibellini, La teologia del XX secolo, Brescia $2007^{6}$, 608: „Sia nella trattazione della Ruether sia in quella della McFague, si propone, in sostanza, una radicalizzazione della trascendenza immanente di Dio al mondo, capace di generare una nuova visione del mondo, tale da acuire una coscienza della inter-relazionalità del tutto e una conseguente responsabilità ecologica".

19 Cf. J. Lovelock, Gaia: A New Look at Life on Earth, Oxford 1982; Id., The Ages of Gaia: A Biography of Our Living Planet, New York 1990. 
groups of people. Evolutionary science obliges us "to study the world from whose history we are largely absent" ${ }^{20}$. Being "made in God's image" cannot apply only to humanity, that is why the doctrine of human supremacy must be challenged. Notions of revelation, redemption, incarnation and soteriology currently depend on an anthropocentric base. She proposes replacing the traditional Christocentric hierarchical paradigm with an ecological paradigm. A scientifically-based evolutionary narrative is the preferred starting point. Through a reinterpretation of Genesis, A. Primavesi unearths a new creation and through the motif of the „spirit” of Genesis considers notions of sin, evil, redemption and salvation, Doctrines of the Trinity, and the role of the Spirit in earth and human history ${ }^{21}$.

Another example of the earth-centered or cosmological-evolutionary ecofeminist efforts may be seen in the thought of Brazilian theologian Ivone Gebara. She tackles systematic theology in depth from an ecofeminist and cosmological framework. The evolutionary scope and the breath of inclusion from cosmology are connected to a concrete option for the marginalized. The task is to challenge and change the Christian theological structures that are implicated in the interconnected destruction of the Earth's body, the human body and relationships to all living bodies. I. Gebara develops an ecofeminist epistemology to assist the great task of reconstructing our cultural, cosmic and vital reference points. She claims that the evolutionary creative processes need to be the foundations for theology, and reshape anthropology in intricate levels of relatedness and ecological interdependence ${ }^{22}$.

An alternative to Gaian imaginary is that of wisdom. Anne Clifford uses biblical wisdom literature as a basis for an ecological theology of creation in a covenant partnership of humans with non-human. Others emphasize wisdom as Sophia who provides a corrective to the hierarchical and dualistic relationship between the divine and creation. To really listen to Sophia ,immanent within nature as God's creation, means we will discover ourselves within rather than apart from our complex global ecosystem"23. A. Primavesi suggests that Wisdom writings are a „science of doxology”, a direct appeal to the human mind to penetrate the order of the cosmos, and to know and love it. Wisdom invites contemplation of the earth, the bringing together of scientific knowledge and a profound sense of wonder and respect ${ }^{24}$.

\footnotetext{
20 A. Primavesi, Sacred Gaia: Theology as Earth Science, London 2000, 21.

21 Cf. A. Primavesi, From Apocalypse to Genesis: Ecology, Feminism and Christianity, Minneapolis 1991. Much of scripture-based ecotheology has seized upon Genesis, and in particular the countless deliberation on dominion of the earth. Cf. also D.S. Cunningham, The Way of All Flesh: Rethinking the Imago Dei, in: C. Deane - Drummond, D. Clough (eds.), Creaturely Theology. On God, Humans and Other Animals, London 2009, $100 \mathrm{ff}$.

22 Cf. I. Gebara, Longing for Running Water: Ecofeminism and Liberation, Minneapolis 1999, $23 \mathrm{ff}$.

23 A. Clifford, Feminist Perspectives on Science, op. cit., 90.

24 Cf. H. Eaton, Introducing Ecofeminist Theologies, op. cit., 82.
} 
C. Deane-Drummond notes that wisdom is not simply emergent property within nature, but rather is also given as a gift from God reflecting the Trinitarian community of persons, expressive of ultimate Wisdom. Instead of seeing the earth as divine in a pantheistic way, for example, the perspective of wisdom encourages those with faith to find in creation the marks of Trinitarian love. Wisdom is not a romantic idealism that ignores the suffering of creations, for wisdom includes the wisdom of the cross. Wisdom also includes the possibility of Gaian science, but it is science kept in its place as science, rather than allow to grow into a mythology beyond its original intention ${ }^{25}$.

What is distinct about some ecofeminist analyses is their inclusion of issues of justice, equity and rights with cosmology and evolution. Without an understanding of the human system of domination in both their ideological and material forms and the intricate connections between the dominations of women and nature, a renewed earth theology may only offer an inspirational orientation. Eco-justice must be bonded to social justice. Some ecofeminist theologians blend the two, some of whom emphasize the earth sciences. The others underline ecofeminist liberation theologies. Ecofeminist theologians articulate the need to develop a radically new way of studying theology in a coalescing ecological, feminist, and liberationist theologies. The starting point for ecofeminist liberation theologies is the plight of the oppressed, in particular women and the natural world ${ }^{26}$. Their goal is to change the world and not simply to reflect and interpret it. Ecofeminist liberation theologies are developed by specific people in particular situations and has many form ${ }^{27}$.

The ecofeminist cosmological perspective is predominantly oriented towards praxis. „These two areas, cosmology and praxis, will likely provide the guiding questions for the expression of belief in God who is both source and the ground for the world we inhabit and our destiny and hope"28.

25 Cf. C. Deane-Drummond, Eco-theology, op. cit., 159ff; Id., Sophia. The Feminine Face of God as a Metaphor for an Ecotheology, Feminist Theology 16 (1997) 11-31.

26 According to I. Gebara, Latin American liberation theology is neither feminist nor ecological. It has not changed the patriarchal anthropology and cosmology upon which Christianity is based. J.M. Ress, Cosmic Theology: Ecofeminism and Panentheism. An Interview with Brazil Feminist Ivone Gebara, Creation and Spirituality Nov/Dec (1993), 9-13.

27 Cf. M. Grey, Sacred Longings: Ecofeminist Theology and Globalisation, London 2003; M.J. Ress, Without a Vision, the People Perish: Reflections on Latin American Ecofeminist Theology, Santiago de Chile 2003. H. Eaton, The Edge of the Sea: The Colonisation of Ecofeminist Religious Perspectives, Critical Review of Books in Religion 11(1998) 57-82; Id., Introducing Ecofeminist Theologies, op. cit., 105-110. In a special issue of the journal Ecotheoloy (2006) edited by H. Eaton, the majority of the articles drew on fieldwork and social analysis of particular contexts where women were actively engaged in practical projects.

28 A. Clifford, Theology and Scientific Cosmology: The Task and the Challenge (Paper delivered at the Catholic Society of America), 1991, 246. 


\section{Anthropological and eschatological issues}

An earth-centred and holistic approach of ecofeminist theologies emphasizes the interdependence of life. Humans are understood to be embedded in and are a part of the natural world. Human being is grounded in and supported by the whole ecological community ${ }^{29}$. Such interdependence can become an ethic or source from which to derive categories of anthropology, like relationship, mutuality, co-operation, participation, responsibility and the common good. A holistic and ecological paradigm counters the embedded tenets of anthropocentrism and hierarchical dualisms. Science, technology and Christian theology are for the most part products of the universal male subject. Ecofeminist theologians envisage a renewed male-female relationship in terms of reciprocity and mutuality. Ecofeminism is also concerned in overcoming the spirit-matter dualism that has plagued the Western view of man and has its roots in patriarchy.

Ecotheologies emphasize the goodness of all of creation. A creation-centred tradition is favoured over a fall-redemption one, wherein all of life is understood as coming into fullness rather than in need of redemption. The matter of creation raises fundamental questions about redemption and salvation, and by extension the notions of sin and grace. Ecofeminism puts sin within the interlocking oppressions of ethnicity, colonialism, class, gender, and the domination of the earth. Sin exists where life cannot thrive. Grace consists in liberating life and those held captive by bonds of oppression.

R. Ruether reinterprets a traditional concept of imago Dei. She situates imago $D e i$ in human intelligence or self consciousness, a product of the evolutionary process which brings with it freedom. The choice we make is for or against the well-being of creation. We alone can sin and invert the evolutionary process ${ }^{30}$.

In A. Primavesi's interpretation of Genesis, human self awareness was gained from God through Eve's action. Once this is seen in a positive light, the whole fallredemption schema, considered anthropocentric, breaks down. Sin now becomes „a choice made in favour of or in rejection of one's fellow earth creatures" ${ }^{\prime 1}$.

Eschatology is also studied through an ecofeminist lens. Catherine Keller reflects on the connections between the „wasting of the world" and historical notions of eschatology. She associates the doctrines of eschatology with creation. Eschatology is reoriented to mean that our eschatological task is to renew „this Earth, this sky, this water", and to make a home for ourselves here ${ }^{32}$.

29 Cf. R.R. Ruether, Sexism and God-Talk: Toward a Feminist Theology, Boston 1983, 87; A. Primavesi, From Apocalypse to Genesis, op. cit., 232f.

30 Cf. R.R. Ruether, Sexism and God-Talk, op. cit., 88; S. McFague, The Body of God, op. cit., 77.

31 A. Primavesi, From Apocalypse to Genesis, op. cit., 233ff.

32 Cf. C. Keller, Women Against Wasting the World: Notes on Eschatology and Ecology, in: I. Diamond, G. Orenstein (eds.), Reweaving the World, op. cit., 249-263; A. Primavesi, From Apocalypse to Genesis, op. cit., 67-84. 
For ecofeminist theology, human responsibility means actively participating in God's continuing creation by mending our broken relations to the earth, to each other and to $\operatorname{God}^{33}$. The ecological paradigm suggests, however, that what we need is a new culture of acceptance of finitude and limits. Elizabeth Green notes that this motif disappears in ecofeminist theology's treatment of the end ${ }^{34}$. Humans must reconcile themselves to their own limits and that is, death. The desire for individual immortality is considered a male prerogative which in its pursuit of transcendence is responsible for the destruction of the planet. Death is a part of nature and is to be accepted. Death has its moment in the circuit of each life. R. Ruether explains: „Our existence as individual ego/organism (...) dissolves back into the cosmic matrix of matter/energy, from which new centres of individuation arise. It is this matrix, rather than our individuated centres being, that is 'everlasting', that subsists beneath the coming to be and passing away of individual beings and even planetary worlds. Acceptance of death, then, is the acceptance of the finitude of our individuated centres of being, but also identification with the larger matrix as our total self that contains us all" ${ }^{35}$. Through our death we actually bring others into existence and achieve the supreme form of relationality.

In some way one can say that for ecofeminist theologies individual life is mortal but collective life is immortal. Jürgen Moltmann notes that this is a sort of hymn to the good earth and does not remark fragility and destructive possibilities inherent to the organism of earth as well as its need of redemption. The earth is a particular creature, it produces plants and animals (Genesis 1,11.24), and it is right to call her „mother of all the living”. However it has nothing to do with pantheism but respects a particular quality and destiny of creature „earth”. But the earth remains always a contingent creature, and will never become eternal goddess Gaia. The earth also, like all the creatures, longs for salvation (Romans $8,19 \mathrm{ff})$ to become „new earth” of eternal creation ${ }^{36}$.

33 D. SoelLe, Thinking about God, London 1990, 39f.: „The more a person develops her creativity, delves into the project of liberation and transcends her own limitations, the more God is God".

34 Cf. E.E. Green, The Transmutation of Theology: Ecofeminist Alchemy and the Christian Tradition, Ökumenismus und Theologie, Jahrbuch der Europäischen Gesellschaft für die theologische Forschung von Frauen, 2 (1994) 48-57, 51f.

35 R.R. Ruether, Sexism and God-Talk, op. cit., 257. Cf. Id., Gaia and God, op. cit., 253.

36 J. Moltmann, Das Kommen Gottes. Christliche Eschatologie, Gütersloh 1995, 302ff, here 304: „Wenn diese Erde schon die Menschen erlösen soll, wer wird dann diese Erde erlösen, und wenn wir im Schoss der Erde und ihren vermeintlich ewigen Kreisläufen geborgen sein sollten, was wird, wenn die Erde im Kältetod stirbt oder in der Sonnenglut zerschmilzt? Der tiefe Respekt vor der 'guten Erde bedeutet nicht, sich mit dem Trost 'beerdigen' zu lassen, in den Würmen und Pflanzen weiterzuleben, sondern auf den Tag zu warten, an dem die Erde sich öffnen wird und die Toten auferstehen werden und die Erde mit ihnen zusammen zu ihrer Neuschöpfung 'auferweckt' wird". 


\section{Observations and critics}

Christopher Lasch believes that the identification of the love of nature with femininity, and of domination over nature through technology with masculinity clouds the underlying narcissistic tendencies that are in both attitudes. He is particularly sharp in his critique of the use of "slogans" that have filtered into the women's movement and the environmental and peace movements. He claims that the conservation of creation must rest on a firmer philosophical foundation that the mystical adoration of nature, which only tends to loss of individuality. The danger of feminist attitudes is that they lead to a surrender of our wills through our romantic dream of symbiotic union. Instead we should face with more realism the tension that comes from the fact that while we are dependent on nature we still transcend $\mathrm{it}^{37}$.

E. Green claims: „I am committed to a theology which incorporates both feminist and an ecological consciousness, yet I do not think that the Christian tradition is as ecologically bankrupt as some ecofeminist theologians implicitly assume"38.

Ecotheologies have pushed a renewed appreciation for a non-hierarchical vision of the Trinity to the current theological debate. The Trinitarian understanding of God posits a dynamic relationality right in the heart of the Godhead replacing the vertical relation of dominance and submission with one of circularity and mutuality. There is a weakness here which concerns the role of the Spirit. Ecofeminist theologians often speak of the Spirit's presence in the world but do not clarify her relationship to the biomorphic spirit which $\mathrm{R}$. Ruether and A. Primavesi, for example, individuate in every form of existence. Christianity has always been careful to distinguish between God and the world and thus safeguard their distinct ontological reality. It is not clear to E. Green how some expressions of ecofeminist theologies, their allegiance to panentheism notwithstanding, actually avoid pantheism, the identification of nature with God which ultimately deprives us both God and the world. Christianity has traditionally maintained that God herself has established the distinction between divine reality and the world. The Spirit informs, transforms and finally transfigures creation ${ }^{39}$.

37 Cf. C. Lasch, The Minimal Self, London 1985, 246-253; C. Dean-Drummond, Ecology in Jürgen Moltmann's Theology, Lewiston 1997, 31f.

38 E.E. Green, The Transmutation of Theology, op. cit., 53. Cf. M. Atkins, Green Theology: Some Methodological Reflections, Theology in Green 6 (1993) 26-32.

39 John Zizioulas, drawing on his Orthodox tradition, notes in Preserving God's Creation, Theology in Green 5 (1993) 21: „In Christian Cosmology the world is contingent and contains in itself no guarantee of survival except in so far as it is in communion with what is now world by nature not what is part of nature - namely God as understood in the Bible". Also J. Moltmann, Gott in der Schöpfung. Ökologische Schöpfungslehre, München 1985, 23ff, underlines that the presence of 
Ecofeminist theology favours the creation-as-birth metaphors. According to E. Green, there is room for powerful birth symbolism, but female symbolism for God required theologically does not necessarily lead us to speak of creation in terms of birth. „Creation by the word can be a source of empowerment to women in naming ourselves and our world as well as a symbol of female transcendence" 40 . If in ecofeminist theology women's freedom means transcending the structures of patriarchy this might be constructed as clashing with the limits ecological integrity imposes. If ecological integrity means maintaining our place in the immanent process of nature this could be understood as destroying women's hope for freedom. This unresolved question is particularly seen in its eschatology. Humans, animals, plants are absorbed into the one God-world which knows no end. This vision has, however, serious consequences. Human beings are deprived of their grounding in the future of God. Bodiliness, an important category for ecfeminist theology, actually has no future. The potentialities released by our death go into a sort of giant lucky dip. The same fate also awaits personhood. The selfhood women have strived to gain, is actually renounced if favour of that „total self that contains us all” ${ }^{41}$. By cosmologizing the resurrection in this way, ecofeminist theology is inadequate to women's basic longings for a reconciled corporeity, true selfhood and a just community. The Christian view of resurrection requires us to grant ultimate worth to bodily reality and the limits this imposes. Grounding the specificity or personhood of the individual enables and preserves true eschatological community. This is better news for women than the prospect of merging with the whole.

Ecofeminist theology tends according to E. Green, not only to reproduce the stereotyping of the patriarchal symbolic order, but also to distance itself from a specifically Christian position. In its reinterpretation of the distorted dualisms ecofeminist theology has almost consistently privileged the „feminine” pole as locus of the divine seen in an exclusively positive way. Ecofeminist theologies needs to theorize more adequately its starting point: which is the relationship between women and nature. Systems which can only guarantee identity through opposition (the distorted dualisms of patriarchy) or uniformity (the God-femalenature continuum of ecofeminism) could be overcome by developing a way of holding equivalence and differences together ${ }^{42}$.

\footnotetext{
the divine Spirit must be differentiated theologically. We have to distinguish between his cosmic, reconciling and redeeming indwelling. Cf. S. Bouma-Prediger, The Greening of Theology. The Ecological Models of Rosemary Radford Ruether, Joseph Sittler, and Jürgen Moltmann, Atlanta 1995, chapters 2 and 5.

40 E.E. GreEn, The Transmutation of Theology, op. cit., 54.

${ }^{41}$ R.R. Ruether, Sexism and God-Talk, op. cit., 257; cf. Id., Gaia and God, op. cit., 251 .

42 Cf. E.E. Green, The Transmutation of Theology, op. cit., 56f.
} 
Elisabeth Moltmann-Wendel also wishes to reinstate the importance of the feminine in God, but she claims that there is no need to return to pagan ideas of a nature Goddess, which is exclusively for women. Rather we can find parallel ideas of the feminine aspect of God in Jewish rabbinic belief about the feminine presence in Shekinah. The Shekinah is something like the cosmic, reconciling and earthly side of God which accompanies Israel into exile. E. Moltmann-Wendel is convinced that the feminine images of God persisted in unwritten "subculture”. There is an additional latent feminine aspect to Jewish hope in the symbolism of milk and honey. When this hidden feminine tradition is uncovered, theology learns to trust this alternative way of seeing reality. The picture of land is significant because it is all-embracing in its hospitality towards both men and women ${ }^{43}$.

\section{Ekologia i antropologia w teologii ekofeministycznej}

\section{STRESZCZENIE}

Ekofeminizm jest ruchem powstałym w latach 70, dostrzegającym związek między degradacją środowiska naturalnego i patriarchalną subordynacją kobiet. Przez pewien czas problem kryzysu ekologicznego i analizy feministyczne wpływały na refleksje teologiczną niezależnie od siebie. Teologia ekofeministyczna (często bardziej radykalna niż inne głosy w eko-teologii) dąży do połączenia ekologii, feminizmu i teologii (najważniejsze przedstawicielki to Rosemary Radford Ruether, Elizabeth Johnson, Sally McFague, Mary Grey, Anne Primavesi, Ivone Gebara, Elizabeth Green i Elisabeth Moltmann-Wendel). Wiele autorek wysuwa hipotezy o odpowiedzialności tradycji żydowskiej i chrześcijańskiej w ucisku natury i kobiet w kontekście patriarchalnego dualizmu i pragnie poddać reinterpretacji niektóre pojęcia teologiczne. Teologia ekofeministyczna przeciwstawia się antropocentryzmowi (ludzkiej dominacji nad naturą) i androcentryzmowi (dominacji mężczyzn nad naturą i kobietami). Dąży ona do przedstawiania Boga bardziej immanentnego w odniesieniu do świata, używając kobiecych symboli i metafor jako wehikułu boskości. Wiele autorek uważa, że klasyczne punkty wyjściowe w teologii są niewystarczające i należy podjąć dialog z naukami o ziemi, kosmologią i teorią ewolucji. Refleksja teologiczna koncentruje się tu na ziemi nie jako maszynie czy jedynie źródle eksploatacji, ale jako żywym organizmie, „ciele Boga”, nawiązując także do hipotezy Gai. Model „ciała Boga” jest jednak trudny do zrozumienia w kontekście ambiwalentnej postawy wobec cielesności we współczesnej kulturze. Innym, bardziej wyważonym wątkiem w refleksji o stworzeniu jest motyw mądrościowy. Poprzez nurty ekofeministycznej teologii wyzwolenia myśl kosmologiczna zostaje następnie powiązana z praktyką społeczną. Ześrodkowana na ziemi, holistyczna

43 Cf. E. Moltmann-Wendel, A Land Flowing with Milk And Honey, London 1986, 98ff; Id., Rückkehr zur Erde, Evangelische Theologie 53 (1993) 406-420. 
teologia ekofeministyczna podkreśla, że człowiek jest częścią wielkiej wspólnoty ekologicznej. Stąd nowa interpretacja takich zagadnień antropologii teologicznej jak imago $D e i$, grzech, łaska i wypełnienie eschatologiczne. Wobec ekofeministycznych ujęć należy zauważyć, że chrześcijaństwo starało się zawsze utrzymać konieczne rozróżnienie ontologiczne między Bogiem a światem. W teologii ekofeministycznej rozróżnienie to, niezależnie od proklamowanego panenteizmu, zaciera się i często ociera o panteizm. Poza tym w eschatologicznej wizji dotyczącej fuzji wszystkich stworzeń gubi się aspekt cielesności i osobowości, który przecież miał odgrywać istotną rolę w wysiłkach teologii feministycznej skierowanych ku emancypacji kobiet. Niektóre autorki wskazują, że nie jest potrzebny powrót do idei kultury pogańskiej, gdyż tradycja żydowsko-chrześcijańska posiada olbrzymi i cenny potencjał dla refleksji ekofeministycznej.

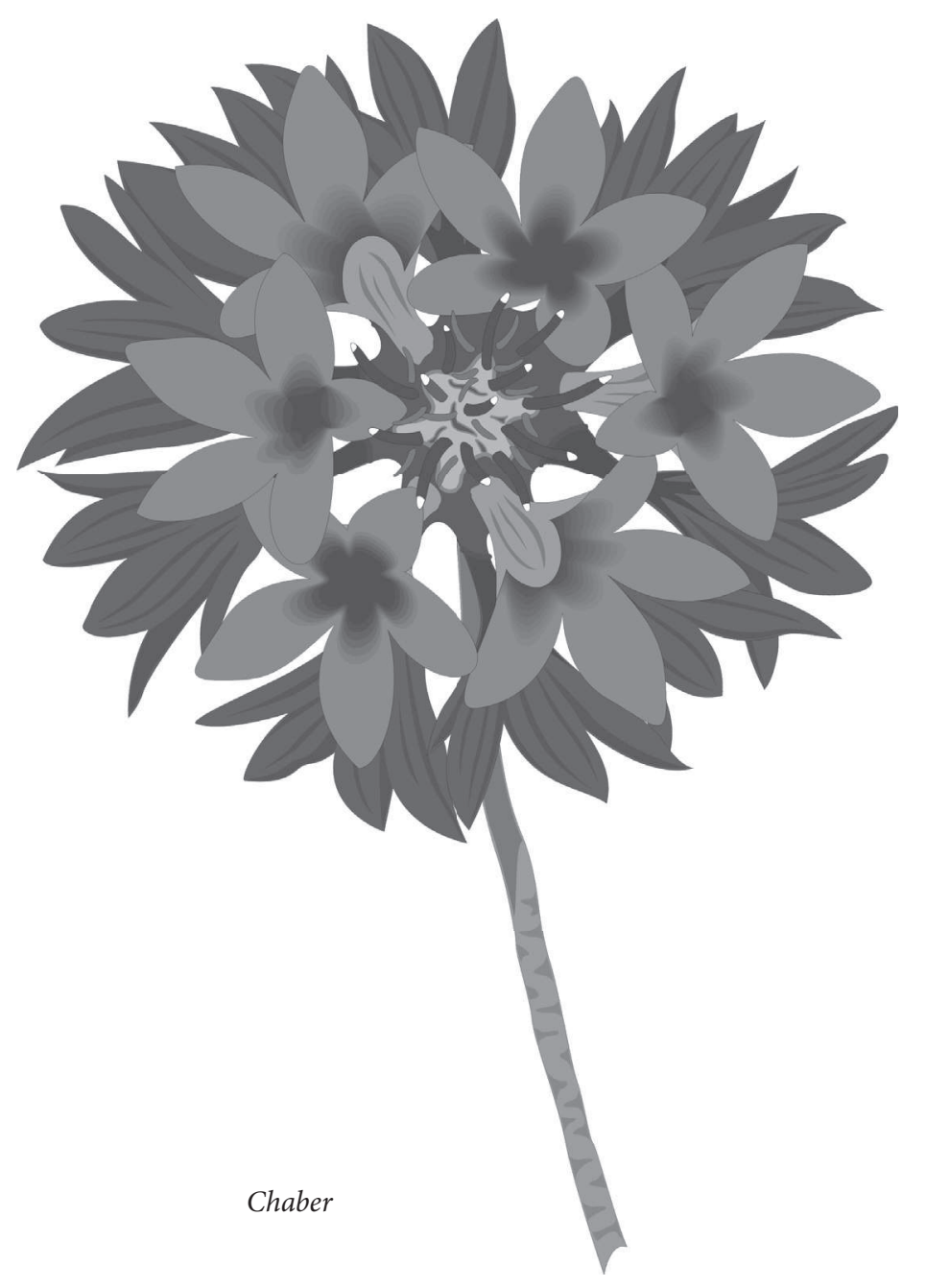

